\title{
Fermentative Biohydrogen Production with Enteric Bacteria Isolated from the Intestine of Wild Common Carp Dwelling in Tarim River Basin
}

\author{
Yanbin Li' ${ }^{1}$ Qin Zhang1*, Hui Jiang2 \\ ${ }^{1}$ College of Biological and Chemical Engineering, Anhui Polytechnic University, Wuhu, China \\ ${ }^{2}$ College of Life Science, Tarim University, Alaer, China \\ Email: *jhtabszq@163.com
}

How to cite this paper: Li, Y.B., Zhang, Q. and Jiang, H. (2020) Fermentative Biohydrogen Production with Enteric Bacteria Isolated from the Intestine of Wild Common Carp Dwelling in Tarim River Basin. Advances in Bioscience and Biotechnology, 11, 442-456.

https://doi.org/10.4236/abb.2020.119030

Received: August 14, 2020

Accepted: September 14, 2020

Published: September 17, 2020

Copyright () 2020 by author(s) and Scientific Research Publishing Inc. This work is licensed under the Creative Commons Attribution International License (CC BY 4.0).

http://creativecommons.org/licenses/by/4.0/

(c) (i) Open Access

\begin{abstract}
The biological hydrogen generating from fermentation of low-cost lignocellulosic feedstocks by hydrogen-producing bacteria has attracted many attentions in recent years. In the present investigation, ten hydrogen-producing bacteria were newly isolated from the intestine of wild common carp (Cyprinus carpio L.), and identified belonging to the genera of Enterobacter and Klebsiella based on analysis of the $16 \mathrm{~S}$ rDNA gene sequence and examination of the physiological and biochemical characteristics. All the isolates inherently owned the ability to metabolize xylose especially the cotton stalk hydrolysate for hydrogen production with hydrogen yield (HY) higher than 100 $\mathrm{mL} \cdot \mathrm{L}^{-1}$. In particular, two isolates, WL1306 and WL1305 obtained higher HY, hydrogen production rate (HPR), and hydrogen production potential (HPP) using cotton stalk hydrolysate as sugar substrate than the mixed sugar of glucose \& xylose, which obtained the HY of $249.5 \pm 29.0,397.0 \pm 36.7 \mathrm{~mL} \cdot \mathrm{L}^{-1}$, HPR of $10.4 \pm 1.2,16.5 \pm 1.5 \mathrm{~mL} \cdot \mathrm{L}^{-1} \cdot \mathrm{h}^{-1}$, HPP of $19.5 \pm 2.3,31.0 \pm 2.8$ $\mathrm{mL} \cdot \mathrm{L}^{-1} \cdot \mathrm{g}^{-1}$ sugar , separately. The generation of soluble metabolites, such as the lactate, formate, acetate, succinate and ethanol reflected the mixed acid fermentation properties of the hydrogen production pathway.
\end{abstract}

\section{Keywords}

Fermentative Biohydrogen Production, Enteric Bacteria, Intestine, Cotton Stalk Hydrolysate, Wild Common Carp

\section{Introduction}

Hydrogen is a clean and efficient energy with zero emission, which can be gen- 
erated from utilization of various renewable feedstocks and wastes [1] [2] [3] [4]. By using carbohydrate-rich biomass, biohydrogen production can be obtained by anaerobic (dark fermentation) and photoheterotrophic (light fermentation) microorganisms [1] [2]. In recent years, biological hydrogen produced by fermentative bacteria through dark fermentation using lignocellulose as substrate has attracted many attentions [5] [6] [7] [8] [9]. Especially, the lignocellulose hydrolysate and fermentative bacteria play important roles in lignocellulose-based hydrogen production.

Cotton stalk is the most widely distributed feedstock in Xinjiang, China. In recent years, high-value utilization of cotton stalk has become a noticeable research focus. Converting the reducing sugar in cotton stalk hydrolysate into high-value chemicals has been of interests; the latest progresses were productions of bioethanol, xylitol and single cell lipid from fermentation of cotton stalk hydrolysate by different fermentative microorganisms [10] [11] [12]. Concerning to biohydrogen production, there are only two reports mentioned about the hydrogen production dynamics using cotton stalk hydrolysate as fermentative substrate [13] [14]. As such, acquirement of high-effective bacteria for efficient hydrogen production and cotton stalk hydrolysate utilization will be of great importance.

Nowadays, exploitation of high-efficiency hydrogen-producing bacteria is vitally important for the hydrogen energy development. The hydrogen-producing bacteria distributed in natural environment are with great diversity, owning to multiple metabolic pathways of hydrogen production [15]. Anaerobic fermentation is regarded as an efficient hydrogen production way with the highest hydrogen generation rate. Anaerobic fermentation of hydrogen is performed by many fermentative microorganisms, including facultative anaerobes of the Enterobacter genus [16] [17], anaerobes of the Clostridium genus [18] [19], Methanogens [20] and Citrobacter species [21]. Amongst, facultative anaerobes of the Enterobacter genus are the most studied hydrogen-producing bacteria, which can produce hydrogen via the formate-hydrogen lytic reaction in the mixed acid fermentation pathway [22] [23].

With the aim to acquire efficient microorganisms for hydrogen production, some hydrogen-producing bacteria have been reported to be isolated from diverse environment, such as sludge [24] [25], waste water [26], soil [27], and so on. It was proved that the hydrogen-producing bacteria isolated from unique environment may obtain good hydrogen production potential as well as specific substrate utilization property. Taguchi et al. (1993) reported a hydrogen-producing bacterium, Clostridium beijerinckii strain AM21B, which was isolated from termites, could utilize starch and glucose as substrate for hydrogen production [28]. A hydrogen-producing bacterium Pseudomonas stutzeri JX442762, which was isolated from thermal soil at Mettur power station, Salem district, Tamil Nadu, India, was reported to be able to use effluent as a good source for the hydrogen production with a yield of $190.03 \pm 0.81 \mathrm{~mL}$ hydrogen [29]. As is well-known, the fish intestine is a specific environment for diverse microorganisms inhabit- 
ing; most studies conducted concerning to the microbial diversity of the fish intestine and the correlation with the host development, physiology, and health [30] [31] [32] up to now, few relating to the exploitation of other functional microorganisms like hydrogen-producing bacteria.

The present study deals with isolation of hydrogen-producing bacteria from the intestine of wild common carp (Cyprinus carpio L.) dwelling in Tarim River Basin, Xinjiang, China. The isolates were identified by phylogenetic analysis of the 16S rDNA sequence and examination of the physiological and biochemical characteristics. The hydrogen production properties of the isolates using various sugar substrates were examined to obtain the strains capable of utilizing cotton stalk hydrolysate for hydrogen production. The soluble metabolites generated during the hydrogen production process using cotton stalk hydrolysate as sugar substrate were analyzed to convince the hydrogen production metabolic pathway of the isolated strains.

\section{Materials and Methods}

\subsection{Materials}

The wild common carp (Cyprinus carpio L.) was caught from Tarim River Basin, the live fish was surface-sterilized and slit the belly soon after being caught, and the intestines were then pulled out and immediately prepared for isolation of hydrogen-producing bacteria.

The cotton stalks used in this research were harvested from a cotton field in Xinjiang Alaer, China. The stalks were dried, milled into fragments, and sifted using a 20-mesh sieve before hydrolysis. The cotton stalk hydrolysate was obtained using the optimum hydrolysis technology and detoxification \& decolorization methods according to the previous report [10] [11] [12]. As a result, the hydrolysate was composed mainly of glucose and xylose, whose concentration ratio is about 3:1 [12], which was prepared as constituent of the fermentation medium.

\subsection{Isolation of Hydrogen-Producing Bacteria Capable of Utilizing Cotton Stalk Hydrolysate}

$1 \mathrm{~g}$ of the intestines and inclusions were weighed and added into $9 \mathrm{~mL}$ sterilized water, then were blended and ground to be the initial suspension, which was then diluted ten times serially. The suspensions diluted $10^{5}, 10^{6}, 10^{7}$ times were transferred with $0.1 \mathrm{~mL}$ into sterile isolation plate and spread evenly, and incubated in a constant-temperature incubator at $37^{\circ} \mathrm{C}$ for $48 \mathrm{~h}$. The isolation medium contained: beef extract $5 \mathrm{~g} / \mathrm{L}$, peptone $10 \mathrm{~g} / \mathrm{L}, \mathrm{NaCl} 5 \mathrm{~g} / \mathrm{L}$, agar $20 \mathrm{~g} / \mathrm{L}$. After incubation, the single colonies were selected and inoculated into $18 \mathrm{~mL}$ tube with $10 \mathrm{~mL}$ liquid medium (the preliminary screening medium included glucose $10 \mathrm{~g} / \mathrm{L}$, xylose $10 \mathrm{~g} / \mathrm{L}$, peptone $10 \mathrm{~g} / \mathrm{L}$, beef extract $5 \mathrm{~g} / \mathrm{L}, \mathrm{NaCl} 5 \mathrm{~g} / \mathrm{L}$; the secondary screening medium added cotton stalk hydrolysate with reducing sugar concentration of $20 \mathrm{~g} / \mathrm{L}$, peptone $10 \mathrm{~g} / \mathrm{L}$, beef extract $5 \mathrm{~g} / \mathrm{L}, \mathrm{NaCl} 5 \mathrm{~g} / \mathrm{L}$ ), and the 
Durham's fermentation tube immersed under the liquid level to collect gas produced by the isolates, the inoculums were cultured at $37^{\circ} \mathrm{C}$ for $24 \mathrm{~h}$. The isolates that could grow and produce $\mathrm{H}_{2}$ gas in the preliminary screening medium were selected to inoculate into the secondary screening medium, and those could grow and produce $\mathrm{H}_{2}$ concentration higher than $50 \mathrm{~mL} / \mathrm{L}_{\text {medium }}$ were considered as hydrogen-producing isolates.

\subsection{Identification of the Isolated Strains}

Genomic DNA was extracted from hydrogen-producing bacteria cells in the exponential phase using an Ezup Column Bacteria Genomic DNA Purification Kit (Sangon, China) in the guidance of the manufacturer's instructions. The 16S rDNA genes were amplified by PCR using the primer pair 27F/1492R. The PCR products were sequenced, and the $16 \mathrm{~S}$ rDNA sequences were aligned and identified against existing sequences in the GenBank database using the BLAST program. Further, the nucleotide sequences of the isolates were aligned with closely related sequence using clustal W program of Mega software (version 6.0) and a phylogenetic tree was constructed to show the relationship between the isolates and the reference strains.

Gram staining of the bacteria was performed using the Hucker method, which was previously reported by Doetsch [33]. The bacterial morphologies were examined using an optical microscope DM1000 LED (Leica, Germany). The bacterial physiological and biochemical characteristics were examined according to the protocols described in the Identification Manual of Systematic Bacteriology [34].

\subsection{Hydrogen Production from Fermentation of Various Sugar Media}

The isolates were cultured on activation slants for $24 \mathrm{~h}$, three loopfuls of activated cells were inoculated into a $250 \mathrm{~mL}$ Erlenmeyer flask containing $100 \mathrm{~mL}$ of seed medium and incubated at $37^{\circ} \mathrm{C}$ on a rotary shaker at $150 \mathrm{rpm}$ within $16 \mathrm{~h}$. The seed medium contained: glucose $10 \mathrm{~g} / \mathrm{L}$, xylose $10 \mathrm{~g} / \mathrm{L}$, peptone $10 \mathrm{~g} / \mathrm{L}$, beef extract $5 \mathrm{~g} / \mathrm{L}, \mathrm{NaCl} 5 \mathrm{~g} / \mathrm{L}$. $\mathrm{OD}_{600}$ s of the seeds were modulated to 1.0 approximately, and inoculated into the fermentation medium with inoculation size of $10 \%(\mathrm{v} / \mathrm{v})$. For each fermentation sample, $175 \mathrm{~mL}$ of fermentation medium was loaded into a $250 \mathrm{~mL}$ Erlenmeyer flask and incubated in a constant-temperature incubator at $37^{\circ} \mathrm{C}$ for $24 \mathrm{~h}$. A rubber plug with a pipe was used for each flask in order to seal the flask and transfer gas produced by each isolate, the fermenter is illustrated as Figure 1. The fermentative media with various sugar were designed as follows: glucose $20 \mathrm{~g} / \mathrm{L}$ (it could be replaced using other designed sugars: 1) xylose $20 \mathrm{~g} / \mathrm{L} ; 2$ ) glucose $10 \mathrm{~g} / \mathrm{L} \&$ xylose $10 \mathrm{~g} / \mathrm{L} ; 3$ ) cotton stalk hydrolysate with reducing sugar concentration of $20 \mathrm{~g} / \mathrm{L}$ ), beef extract $5 \mathrm{~g} / \mathrm{L}$, peptone $10 \mathrm{~g} / \mathrm{L}, \mathrm{NaCl}$ $5 \mathrm{~g} / \mathrm{L}, \mathrm{KH}_{2} \mathrm{PO}_{4} 0.5 \mathrm{~g} / \mathrm{L}, \mathrm{MgSO}_{4} \cdot 7 \mathrm{H}_{2} \mathrm{O} 0.5 \mathrm{~g} / \mathrm{L}$. After fermentation, the volume and concentration of hydrogen gas were measured, and the sugar content in the fermentative broth was examined. In the treatment of using cotton stalk hydrolysate 


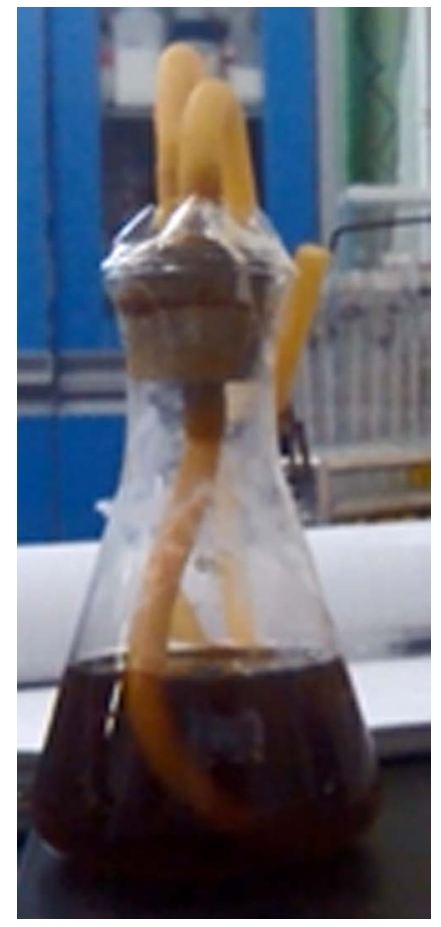

Figure 1. The fermenter for biohydrogen production.

as sugar substrate, the main by-products such as succinate, citrate, lactate, acetate, ethanol, were also examined.

\subsection{Analytical Methods}

Volume of the hydrogen gas was measured by $1 \mathrm{~mol} / \mathrm{L} \mathrm{NaOH}$ displacement in an inverted burette, and a handled hydrogen detector (KP810H20, Henan Zhong'an Electronic Detection Technology Co. Ltd., China) was used to examine the biohydrogen concentration. At end of the fermentation, the aqueous samples were centrifuged at $8000 \times \mathrm{g}$ for $10 \mathrm{~min}$ and filtered through syringe filters with 0.22 $\mu \mathrm{m}$ membrane before being analyzed.

The total concentration of reducing sugars in the broth was determined by the 3,5-dinitryl-salicylic acid reagent (DNS) method reported previously [35]. Glucose and xylose concentrations were detected by high-performance liquid chromatograph (HPLC) (Shimadzu LC-2A) using a refractive index detector. A Cosmosil $\mathrm{NH}_{2}$ column $(5 \mu \mathrm{m}, 4.6 \mathrm{~mm} \times 250 \mathrm{~mm})$ was used with a solution of acetonitrile and water (75:25) as the eluent. Analysis was developed using an eluent flow rate of $1.0 \mathrm{~mL} / \mathrm{min}$ at a temperature of $40^{\circ} \mathrm{C}$, and the injection volume of 20 $\mu \mathrm{L}$.

The concentrations of succinate, citrate and lactate were measured by a high-performance liquid chromatograph (HPLC) (Waters2695) with a UV-detector and using a $\mathrm{C}_{18}$ silica gel column Sinochrom ODS-BP $(4.6 \mathrm{~mm} \times 250 \mathrm{~mm} \times 5$ $\mu \mathrm{m})$. The $\mathrm{NH}_{4} \mathrm{H}_{2} \mathrm{PO}_{4}$ solution of $10 \mathrm{mmol} / \mathrm{L}$ was used as mobile phase with a flow rate of $1.0 \mathrm{~mL} / \mathrm{min}$, the temperature of column was $37^{\circ} \mathrm{C}$, the detection wavelength was $210 \mathrm{~nm}$, and the injection volume was $20 \mu \mathrm{L}$. The concentrations of 
acetate and ethanol were verified by gas chromatography (GC) (Aglient6890N, J\&W Scientific) with a flow rate of $2 \mathrm{~mL} / \mathrm{min}$ over the hp-FFAP column (30 $\mathrm{m} \times$ $0.25 \mathrm{~mm} \times 0.25 \mu \mathrm{m}$ ) using flame ionization detector (FID) detector with a nitrogen carrier gas. The process conditions were conducted as follows: injector temperature, $220^{\circ} \mathrm{C}$; detector temperature $280^{\circ} \mathrm{C}$; the temperature profile 60 , $170^{\circ} \mathrm{C}$ with 6 min run time.

\section{Results and Discussion}

\subsection{Isolation and Identification of the Hydrogen-Producing Bacteria}

The intestine of wild common carp (Cyprinus carpio L.) is a comfortable habitat for many fermentative bacteria. More than 50 bacteria isolated from the isolation medium and purified for follow-up experiment. Among them, 22 bacteria were selected as candidate strains with the ability to grow and produce $\mathrm{H}_{2}$ gas in the preliminary screening medium. On the basis, 10 bacteria, which obtained $\mathrm{OD}_{600}$ of growth and concentration of hydrogen production higher than 1.0 and $50.0 \mathrm{~mL} / \mathrm{L}_{\text {medium }}$ separately in 24-hour culture, were picked out as the aimed hydrogen-producing isolates (Figure 2). All the ten bacteria were designated with numbers of WL1306, WL1315, WL1302, WL1307, WL1318, WL1308, WL1305, WL1310, WL1309, WL1312. All the bacteria are rod-shaped and Gram-staining negative. Physiological and biochemical characteristics of the isolates were also examined, and the results were illustrated in Table 1 , which were similar to properties belonging to the genera of Enterobacter and Klebsiella.

Furthermore, the bacterial sequences of 16S rDNA genes (approximately 1.5 $\mathrm{kb}$ ) were sequenced and then submitted to the GenBank to obtain the accession numbers of KT328451, KT328457, KT328449, KT328452, KT328458, KT328453, KT328450, KT328455, KT328454, KT328456. The determined sequences were compared with the available $16 \mathrm{~S}$ rDNA gene sequences from the GenBank database by the BLAST search program, and a phylogenetic tree was constructed to show the relationship between isolates deduced from the determined sequences and the reference bacterial strains (Figure 3). It was deduced from Figure 3 that the isolates could be divided into two genera of Enterobacter and Klebsiella, amongst, five species, such as WL1310, WL1302, WL1318, WL1306, WL1308,

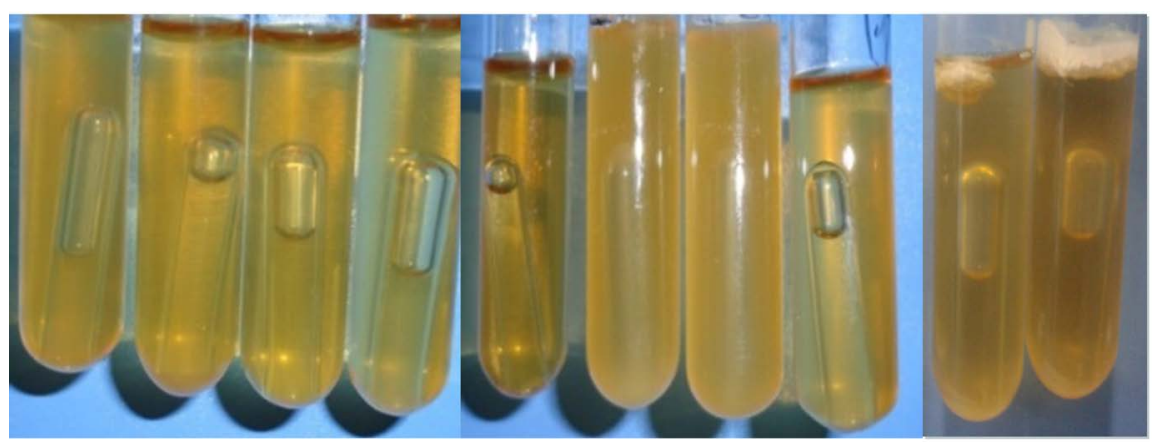

Figure 2. Hydrogen gas generation in screening medium. 


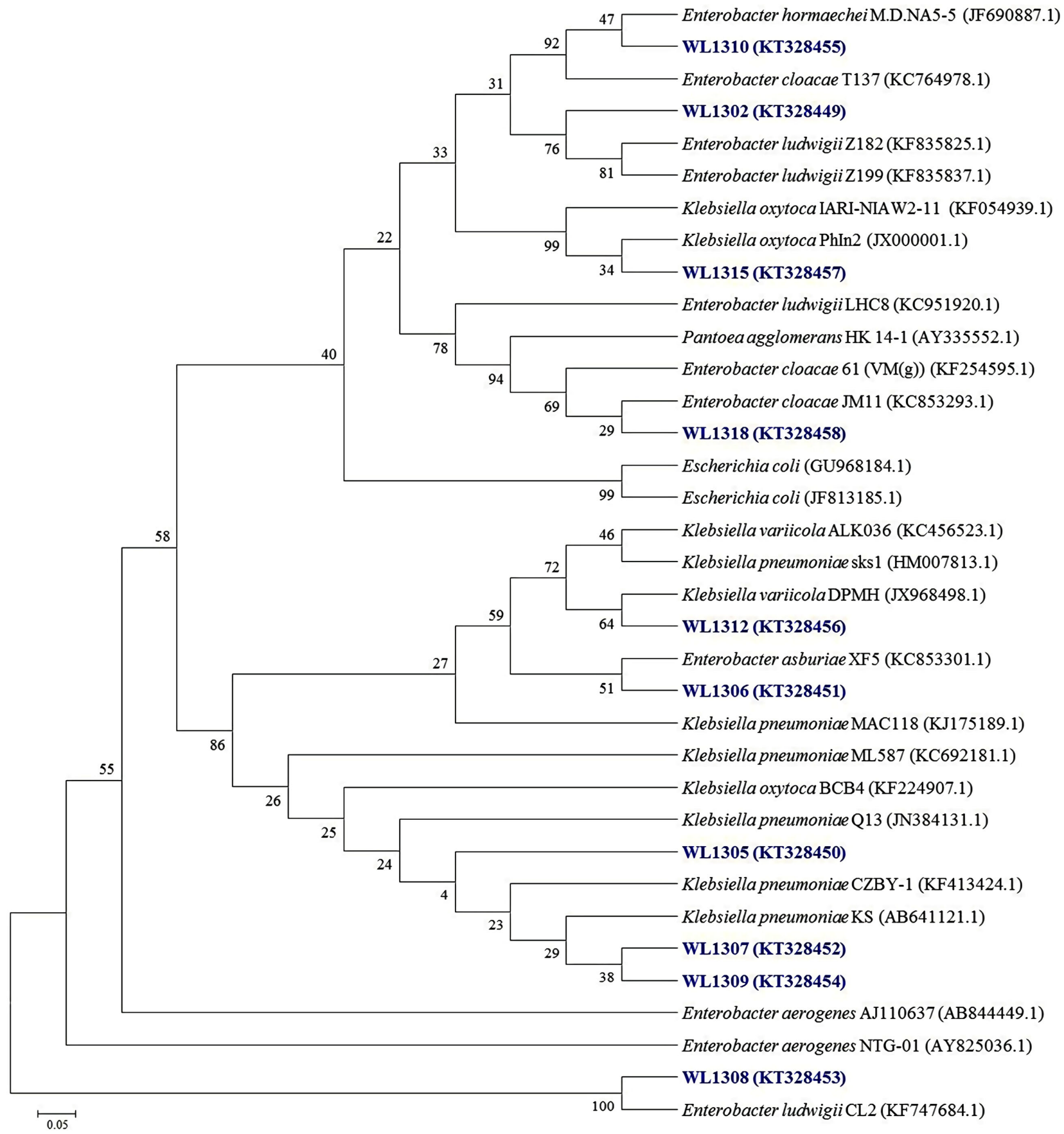

Figure 3. Neighbour-joining phylogenetic tree showing the phylogenetic position of the isolates, based on 16S rDNA gene sequences of Enterobacteriaceae. The numbers at the nodes indicate the levels of bootstrap support based on the neighbor-joining analysis of 1000 resampled data sets. Bar 0.05 substitutions per nucleotide position.

were related to Enterobacter genus. On the other hand, five species, such as WL1315, WL1312, WL1305, WL1307, WL1309, were grouped into Klebsiella genus. Species in genera of Enterobacter and Klebsiella are the mostly reported facultative anaerobic hydrogen-producing bacteria, which can utilize various substrates for hydrogen production via mix acid pathway [36] [37] [38] [39]. The dominant hydrogen-producing bacteria isolated from the intestine of wild 
Table 1. Physiological and biochemical characteristics of the hydrogen-producing bacteria.

\begin{tabular}{|c|c|c|c|c|c|c|c|c|c|c|}
\hline Characteristics & $\begin{array}{c}\text { WL } \\
1306\end{array}$ & $\begin{array}{c}\text { WL } \\
1315\end{array}$ & $\begin{array}{c}\text { WL } \\
1302\end{array}$ & $\begin{array}{c}\text { WL } \\
1307\end{array}$ & $\begin{array}{c}\text { WL } \\
1318\end{array}$ & $\begin{array}{c}\text { WL } \\
1308\end{array}$ & $\begin{array}{c}\text { WL } \\
1305\end{array}$ & $\begin{array}{c}\text { WL } \\
1310\end{array}$ & $\begin{array}{c}\text { WL } \\
1309\end{array}$ & $\begin{array}{c}\text { WL } \\
1312\end{array}$ \\
\hline Gram staining & - & - & - & - & - & - & - & - & - & - \\
\hline Shape & Rod & Rod & Rod & Rod & Rod & Rod & Rod & Rod & Rod & Rod \\
\hline Citrate utilization & - & + & + & + & + & + & + & + & + & + \\
\hline Gelatin liquefaction & + & + & + & + & + & + & + & + & + & + \\
\hline Methyl-red test & - & + & - & + & - & - & + & - & + & - \\
\hline $\mathrm{V}$-P test & + & + & + & + & + & + & + & + & + & + \\
\hline Production of indole & + & + & + & + & + & + & + & + & + & + \\
\hline Production of $\mathrm{H}_{2} \mathrm{~S}$ & - & - & - & - & - & - & - & - & - & - \\
\hline Starch hydrolysis & + & + & + & + & + & + & + & + & + & + \\
\hline Litmus milk & + & + & + & + & + & + & + & + & + & + \\
\hline Lipase & - & - & - & - & - & - & - & - & - & - \\
\hline Urease & - & - & - & - & - & - & - & - & - & - \\
\hline
\end{tabular}

+: positive; -: negative.

common carp were just the two types, indicating that the bacteria isolated from this unique environment might possess high hydrogen production potential.

\subsection{Fermentative Hydrogen Production Properties of the Isolates}

In order to make clear the hydrogen production potential of the isolates, the hydrogen producing properties using various reducing sugar were examined (Figure 4). Glucose is the essential carbon source for hydrogen producing bacteria, which was mentioned in many reports [40] [41] [42]. All the ten isolates could effectively produce hydrogen in the glucose medium with hydrogen yield (HY), hydrogen production rate (HPR), hydrogen production potential (HPP) higher than $100 \mathrm{~mL} \cdot \mathrm{L}^{-1}, 5.5 \mathrm{~mL} \cdot \mathrm{L}^{-1} \cdot \mathrm{h}^{-1}, 10.5 \mathrm{~mL} \cdot \mathrm{L}^{-1} \cdot \mathrm{g}^{-1}$ sugar , illustrating that all the ten isolated bacteria could utilize glucose as elementary sugar substrate for hydrogen production. Not only that, the isolates could also utilize xylose for hydrogen production. Especially, the isolates obtained higher HY, HPR and HPP using xylose as sugar substrate than glucose, indicating that the isolates inherently owned the ability to metabolize xylose for hydrogen production (Table 2).

Noticeably, the isolates also obtained high HY, HPR and HPP using glucose \& xylose and cotton stalk hydrolysate as sugar substrate, showing their abilities to utilize glucose and xylose simultaneously for hydrogen production. Several strains, such as WL1310, WL1309, WL1312 acquired remarkably high hydrogen production with $\mathrm{HY}$ of $718.5 \pm 9.2,679.5 \pm 4.9,906.0 \pm 8.5 \mathrm{~mL} \cdot \mathrm{L}^{-1}$, respectively, using glucose \& xylose as sugar substrate. Moreover, all the isolates could utilize cotton stalk hydrolysate for hydrogen production with HY higher than 100 $\mathrm{mL} \cdot \mathrm{L}^{-1}$, particularly, two strains, WL1306 and WL1305 obtained higher HY, HPR 

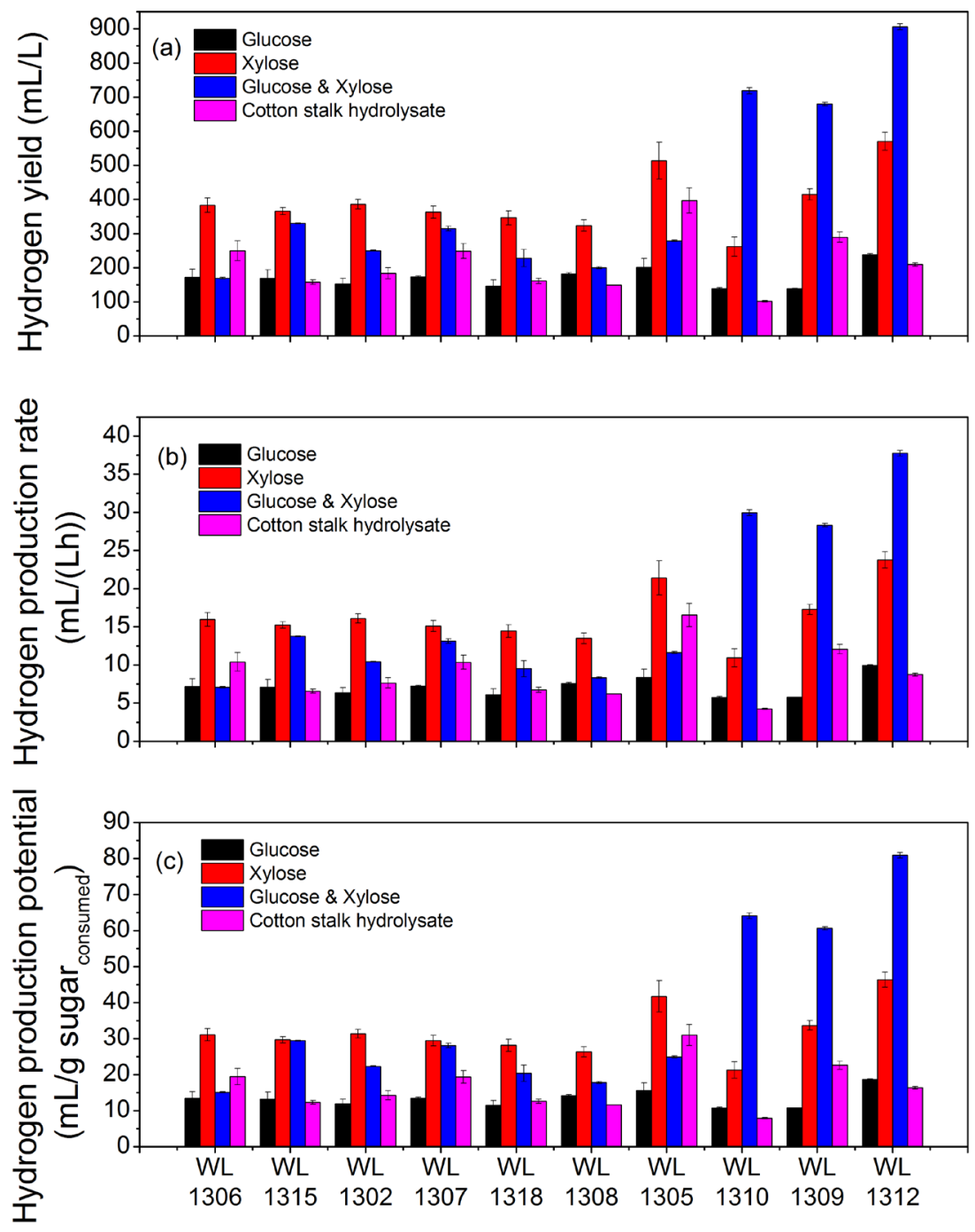

\section{Enteric bacteria}

Figure 4. Hydrogen production by the hydrogen-producing bacteria from fermentation of various sugar substrate (glucose, xylose, glucose \& xylose, cotton stalk hydrolysate). (a) Hydrogen yield (HY); (b) Hydrogen production rate (HPR); (c) Hydrogen production potential (HPP).

Table 2. Hydrogen production by the hydrogen-producing bacteria from fermentation of various sugar media.

\begin{tabular}{|c|c|c|c|c|c|c|c|c|c|c|c|}
\hline $\begin{array}{c}\text { Sugar } \\
\text { substrates }\end{array}$ & Items & WL1306 & WL1315 & WL1302 & WL1307 & WL1318 & WL1308 & WL1305 & WL1310 & WL1309 & WL1312 \\
\hline \multirow[b]{2}{*}{ Glucose } & $\begin{array}{c}\mathrm{HY} \\
\left(\mathrm{mL} \cdot \mathrm{L}^{-1}\right)\end{array}$ & $172.0 \pm 24.0$ & $169.5 \pm 24.7$ & $152.5 \pm 16.3$ & $172.5 \pm 3.5$ & $146.5 \pm 17.7$ & $181.5 \pm 3.5$ & $200.5 \pm 26.2$ & $138.0 \pm 2.8$ & $138.5 \pm 0.7$ & $238.5 \pm 2.1$ \\
\hline & $\begin{array}{c}\text { HPR } \\
\left(\mathrm{mL} \cdot \mathrm{L}^{-1} \cdot \mathrm{h}^{-1}\right)\end{array}$ & $7.2 \pm 1.0$ & $7.1 \pm 1.0$ & $6.4 \pm 0.6$ & $7.2 \pm 0.1$ & $6.1 \pm 0.7$ & $7.6 \pm 0.1$ & $8.4 \pm 1.0$ & $5.8 \pm 0.1$ & $5.8 \pm 0.1$ & $9.9 \pm 0.1$ \\
\hline \multirow{2}{*}{ Xylose } & $\begin{array}{c}\mathrm{HY} \\
\left(\mathrm{mL} \cdot \mathrm{L}^{-1}\right)\end{array}$ & $383.0 \pm 21.2$ & $365.5 \pm 10.6$ & $386.0 \pm 14.1$ & $362.5 \pm 17.7$ & $346.5 \pm 20.5$ & $324.0 \pm 17.0$ & $514.0 \pm 53.7$ & $262.0 \pm 28.3$ & $414.5 \pm 16.3$ & $570.5 \pm 26.2$ \\
\hline & $\begin{array}{c}\text { HPR } \\
\left(\mathrm{mL} \cdot \mathrm{L}^{-1} \cdot \mathrm{h}^{-1}\right)\end{array}$ & $16.0 \pm 0.9$ & $15.2 \pm 0.4$ & $16.1 \pm 0.6$ & $15.1 \pm 0.7$ & $14.4 \pm 0.9$ & $13.5 \pm 0.7$ & $21.4 \pm 2.2$ & $10.9 \pm 1.2$ & $17.3 \pm 0.7$ & $23.7 \pm 1.1$ \\
\hline
\end{tabular}


Continued

\begin{tabular}{|c|c|c|c|c|c|c|c|c|c|c|c|}
\hline & $\begin{array}{c}\text { HPP } \\
\left(\mathrm{mL} \cdot \mathrm{L}^{-1} \cdot \mathrm{g}_{\text {sugar }}^{-1}\right)\end{array}$ & $31.1 \pm 1.7$ & $29.7 \pm 0.9$ & $31.4 \pm 1.1$ & $29.5 \pm 1.4$ & $28.2 \pm 1.7$ & $26.3 \pm 1.4$ & $41.8 \pm 4.3$ & $21.3 \pm 2.3$ & $33.7 \pm 1.3$ & $46.3 \pm 2.1$ \\
\hline & $\begin{array}{c}\mathrm{HY} \\
\left(\mathrm{mL} \cdot \mathrm{L}^{-1}\right)\end{array}$ & $169.5 \pm 2.1$ & $330.0 \pm 1.4$ & $250.0 \pm 1.4$ & $315.0 \pm 7.1$ & $228.0 \pm 25.5$ & $200.0 \pm 2.8$ & $279.0 \pm 2.8$ & $718.5 \pm 9.2$ & $679.5 \pm 4.9$ & $906.0 \pm 8.5$ \\
\hline \multirow[t]{3}{*}{$\begin{array}{l}\text { Glucose \& } \\
\text { Xylose }\end{array}$} & $\begin{array}{c}\text { HPR } \\
\left(\mathrm{mL} \cdot \mathrm{L}^{-1} \cdot \mathrm{h}^{-1}\right)\end{array}$ & $7.1 \pm 0.1$ & $13.8 \pm 0.1$ & $10.4 \pm 0.1$ & $13.1 \pm 0.3$ & $9.5 \pm 1.0$ & $8.3 \pm 0.1$ & $11.6 \pm 0.1$ & $29.9 \pm 0.4$ & $28.3 \pm 0.2$ & $37.8 \pm 0.4$ \\
\hline & $\begin{array}{c}\text { HPP } \\
\left(\mathrm{mL} \cdot \mathrm{L}^{-1} \cdot \mathrm{g}_{\text {sugar }}^{-1}\right)\end{array}$ & $15.1 \pm 0.1$ & $29.5 \pm 0.1$ & $22.3 \pm 0.1$ & $28.1 \pm 0.6$ & $20.4 \pm 2.1$ & $17.9 \pm 0.3$ & $24.9 \pm 0.3$ & $64.2 \pm 0.8$ & $60.7 \pm 0.5$ & $80.9 \pm 0.8$ \\
\hline & $\begin{array}{c}\mathrm{HY} \\
\left(\mathrm{mL} \cdot \mathrm{L}^{-1}\right)\end{array}$ & $249.5 \pm 29.0$ & $157.5 \pm 6.4$ & $183.5 \pm 16.3$ & $248.5 \pm 61.5$ & $161.5 \pm 7.8$ & $149.0 \pm 0.0$ & $397.0 \pm 36.7$ & $101.5 \pm 2.1$ & $289.5 \pm 14.8$ & $209.5 \pm 4.9$ \\
\hline \multirow[t]{2}{*}{$\begin{array}{c}\text { Cotton } \\
\text { stalk } \\
\text { hydrolysate }\end{array}$} & $\begin{array}{c}\mathrm{HPR} \\
\left(\mathrm{mL} \cdot \mathrm{L}^{-1} \cdot \mathrm{h}^{-1}\right)\end{array}$ & $10.4 \pm 1.2$ & $6.6 \pm 0.3$ & $7.6 \pm 0.7$ & $10.4 \pm 0.9$ & $6.7 \pm 0.3$ & $6.2 \pm 0.0$ & $16.5 \pm 1.5$ & $4.2 \pm 0.1$ & $12.1 \pm 0.6$ & $8.7 \pm 0.2$ \\
\hline & $\begin{array}{c}\text { HPP } \\
\left(\mathrm{mL} \cdot \mathrm{L}^{-1} \cdot \mathrm{g}_{\text {sugar }}^{-1}\right)\end{array}$ & $19.5 \pm 2.3$ & $12.3 \pm 0.5$ & $14.3 \pm 1.2$ & $19.4 \pm 1.7$ & $12.6 \pm 0.6$ & $11.6 \pm 0.0$ & $31.0 \pm 2.8$ & $7.9 \pm 0.2$ & $22.6 \pm 1.1$ & $16.6 \pm 0.5$ \\
\hline
\end{tabular}

HY: hydrogen yield; HPR: hydrogen production rate; HPP: hydrogen production potential.

and HPP using cotton stalk hydrolysate as sugar substrate than the mixed sugar of glucose \& xylose, which obtained the HY of $249.5 \pm 29.0,397.0 \pm 36.7 \mathrm{~mL} \cdot \mathrm{L}^{-1}$, HPR of $10.4 \pm 1.2,16.5 \pm 1.5 \mathrm{~mL} \cdot \mathrm{L}^{-1} \cdot \mathrm{h}^{-1}$, HPP of $19.5 \pm 2.3,31.0 \pm 2.8$ $\mathrm{mL} \cdot \mathrm{L}^{-1} \cdot \mathrm{g}^{-1}$ sugar , separately, illuminating that the two bacteria might be more liable to utilize cotton stalk hydrolysate for hydrogen production.

\subsection{Soluble Metabolites Analysis of Hydrogen Production from Cotton Stalk Hydrolysate}

The ten isolates exhibited different hydrogen production performance when using cotton stalk hydrolysate as sugar substrate as shown in the above section, indicating that the hydrogen production properties might be different. So analysis of soluble metabolites generated during the hydrogen production process would be necessary. Enterobacter and Klebsiella species are known to carry out mixed acid fermentation while using sugars as the carbon substrate [36] [37]. In the present work, the soluble metabolites produced from the enteric bacteria during dark $\mathrm{H}_{2}$ fermentation were lactate, formate, acetate, succinate and ethanol (Figure 5). Production of lactate was predominant in the isolates of WL1307 and WL1309, accounting for $45.4 \%(\mathrm{w} / \mathrm{w})$ and $57.0 \%(\mathrm{w} / \mathrm{w})$ of total soluble metabolites formation in each strain. While production of succinate was predominant in the strains of WL1308 and WL1312, accounting for $48.3 \%(\mathrm{w} / \mathrm{w})$ and $42.3 \%$ $(\mathrm{w} / \mathrm{w})$ of total soluble metabolites formation in each strain. The ethanol produced at a comparable high concentration in strains WL1305, WL1309, WL1315, WL1307, which obtained ethanol concentration higher than $0.65 \mathrm{~g} / \mathrm{L}$. Moreover, acetate production was apparently not the preferable metabolic pathway for the enteric bacteria, since the contribution of acetate to soluble metabolites was, in general, less than $25 \%$ of the total soluble metabolites, especially, the acetate concentrations, produced by WL1308 and WL1312, were almost close to $0 \mathrm{~g} / \mathrm{L}$. Although the formate concentrations were higher than acetate in every strains, 




Figure 5. The soluble metabolites produced from the enteric bacteria during the hydrogen production process using cotton stalk hydrolysate as substrate.

the proportion of formate in the total soluble metabolites was still low, implying that the isolates producing hydrogen through formate hydrogen lyse pathway may affected by other metabolites generating branch pathway. In contrast, the soluble metabolite composition resulting from Enterobacter genus was very different from that for the Klebsiella genus. Klebsiella species are common alcohol producers and frequently used for the production of commercially valuable alcohol [43]. Indeed, the major product for Klebsiella sp. during dark $\mathrm{H}_{2}$ fermentation was ethanol, while smaller quantities of aecetate and formate were formed in most Klebsiella species.

\section{Conclusion}

Ten hydrogen-producing bacteria WL1306, WL1315, WL1302, WL1307, WL1318, WL1308, WL1305, WL1310, WL1309, WL1312, newly isolated from the intestine of wild common carp (Cyprinus carpio L.), which were rod-shaped and Gram-staining negative strains belonging to the genera of Enterobacter and Klebsiella based on the 16S rDNA gene sequence analysis and examination of the physiological and biochemical characteristics. All the ten hydrogen-producing bacteria were capable of producing hydrogen gas in the media using glucose, xylose, glucose \& xylose and cotton stalk hydrolysate as sugar substrate. Especially, all the isolates obtained higher HY, HPR, HPP using xylose as sugar substrate than glucose, indicating that the isolates inherently owned the ability to metabolize xylose for hydrogen production. Moreover, all the isolates could utilize cotton stalk hydrolysate for hydrogen production with hydrogen yield (HY) 
higher than $100 \mathrm{~mL} \cdot \mathrm{L}^{-1}$. In particular, two isolates, WL1306 and WL1305 obtained higher HY, HPR and HPP using cotton stalk hydrolysate as sugar substrate than the mixed sugar of glucose \& xylose, which obtained the HY of 249.5 $\pm 29.0,397.0 \pm 36.7 \mathrm{~mL} \cdot \mathrm{L}^{-1}, \mathrm{HPR}$ of $10.4 \pm 1.2,16.5 \pm 1.5 \mathrm{~mL} \cdot \mathrm{L}^{-1} \cdot \mathrm{h}^{-1}$, HPP of 19.5

$\pm 2.3,31.0 \pm 2.8 \mathrm{~mL} \cdot \mathrm{L}^{-1} \cdot \mathrm{g}_{\text {sugar }}^{-1}$, separately, illuminating that the two bacteria might be more liable to utilize cotton stalk hydrolysate for hydrogen production. The generation of soluble metabolites, such as the lactate, formate, acetate, succinate and ethanol reflected the mixed acid fermentation properties of the hydrogen production pathway. In summary, the present investigation provided an effective way to isolate the hydrogen-producing bacteria from the intestine of wild common carp (Cyprinus carpio L.) for fermentative biohydrogen production using cotton stalk hydrolysate as carbon source, and revealed the hydrogen production potential and the soluble metabolites generating properties of the isolates.

\section{Acknowledgements}

This work was financially supported by the National Natural Science Foundation of China (21406150), the Key Research and Development Project of Anhui Province in China (201904a07020003), and the Talent Start-up Fund of Anhui Polytechnic University in China (2018YQQ029).

\section{Conflicts of Interest}

The authors declare no conflicts of interest regarding the publication of this paper.

\section{References}

[1] Rezania, S., Din, M.F.D., Taib, S.M., Sohaili, S., Kamyab, C.H. and Saha, B.B. (2017) Review on Fermentative Biohydrogen Production from Water Hyacinth, Wheat Straw and Rice Straw with Focus on Recent Perspectives. International Journal of Hydrogen Energy, 42, 20955-20969. https://doi.org/10.1016/j.ijhydene.2017.07.007

[2] Azwar, M.Y., Hussain, M.A. and Abdul-Wahab, A.K. (2014) Development of Biohydrogen Production by Photobiological, Fermentation and Electrochemical Processes: A Review. Renewable \& Sustainable Energy Reviews, 31, 158-173. https://doi.org/10.1016/j.rser.2013.11.022

[3] Kalinci, Y., Hepbasli, A. and Dincer, I. (2009) Biomass-Based Hydrogen Production: A Review and Analysis. International Journal of Hydrogen Energy, 34, 8799-8817. https://doi.org/10.1016/j.ijhydene.2009.08.078

[4] Ahluwalia, R.K. and Wang, X. (2005) Direct Hydrogen Fuel Cell Systems for Hybrid Vehicles. Journal of Power Sources, 139, 152-164. https://doi.org/10.1016/j.jpowsour.2004.07.018

[5] Asadi, N. and Zilouei, H. (2017) Optimization of Organosolv Pretreatment of Rice Straw for Enhanced Biohydrogen Production Using Enterobacter aerogenes. Bioresource Technology, 227, 335-344. https://doi.org/10.1016/j.biortech.2016.12.073

[6] Lopez-Hidalgo, A.M., Sánchez, A. and León-Rodríguez, A.D. (2017) Simultaneous Production of Bioethanol and Biohydrogen by Escherichia coli WDHL Using Wheat 
Straw Hydrolysate as Substrate. Fuel, 188, 19-27. https://doi.org/10.1016/j.fuel.2016.10.022

[7] Özgür, E. and Peksel, B. (2013) Biohydrogen Production from Barley Straw Hydrolysate through Sequential Dark and Photofermentation. Journal of Cleaner Production, 52, 14-20. https://doi.org/10.1016/j.jclepro.2013.02.035

[8] Zhang, K., Ren, N.Q. and Wang, A.J. (2015) Fermentative Hydrogen Production from Corn Stover Hydrolyzate by Two Typical Seed Sludges: Effect of Temperature. International Journal of Hydrogen Energy, 40, 3838-3848. https://doi.org/10.1016/j.ijhydene.2015.01.120

[9] Kumar, K., Roy, S. and Das, D. (2013) Continuous Mode of Carbon Dioxide Sequestration by $C$. sorokiniana and Subsequent Use of Its Biomass for Hydrogen Production by E. cloacae IIT-BT 08. Bioresource Technology, 145, 116-122. https://doi.org/10.1016/j.biortech.2013.01.137

[10] Zhang, Q., Li, Y., Li, J. and Ma, C.M. (2011) Dilute Acid Hydrolysis of Cotton Stalks and Ethanol Production from Hydrolytic Liquids. Proceedings 2011 International Conference on Materials for Renewable Energy \& Environment (ICMREE 2011), Shanghai, 20-22 May 2011, 459-463. https://doi.org/10.1109/ICMREE.2011.5930852

[11] Zhang, Q., Li, Y., Xia, L., Liu, Z. and Pu, Y. (2014) Enhanced Xylitol Production from Statistically Optimized Fermentation of Cotton Stalk Hydrolysate by Immobilized Candida tropicalis. Chemical and Biochemical Engineering Quarterly, 28, 13-19.

[12] Zhang, Q., Li, Y.B. and Xia, L.M. (2014) An Oleaginous Endophyte Bacillus subtilis HB1310 Isolated from Thin-Shelled Walnut and Its Utilization of Cotton Stalk Hydrolysate for Lipid Production. Biotechnology for Biofuels, 7, 152-165. https://doi.org/10.1186/s13068-014-0152-4

[13] Zhu, X.P., Hou, M.Y., Yang, J.C., Yuan, L.H., Xu, M. and Zhang Q. (2017) Hydrogen Production Dynamics of Cotton Stalk Hydrolysate Batch Fermentation by Klebsiella sp. The Food Industry, 38, 201-204. (In Chiese)

[14] Li, Y.B., Zhang, Q., Deng, L., Liu, Z., Hui, J. and Wang, F. (2018) Biohydrogen Production from Fermentation of Cotton Stalk Hydrolysate by Klebsiella sp. WL1316 Newly Isolated from Wild Carp (Cyprinus carpio L.) of the Tarim River Basin. Applied Microbiology \& Biotechnology, 102, 4231-4242. https://doi.org/10.1007/s00253-018-8882-Z

[15] Wang, J. and Wan, W. (2009) Factors Influencing Fermentative Hydrogen Production: A Review. International Journal of Hydrogen Energy, 34, 799-811. https://doi.org/10.1016/j.ijhydene.2008.11.015

[16] Shin, J., Hyun Yoon, J., Eun, K.A., Kim, M., Sim, S.J. and Park, T.H. (2007) Fermentative Hydrogen Production by the Newly Isolated Enterobacter asburiae SNU-1. International Journal of Hydrogen Energy, 32, 192-199. https://doi.org/10.1016/j.ijhydene.2006.08.013

[17] Ngo, T.A., Nguyn, T.H. and Bui, H.T.V. (2012) Thermophilic Fermentative Hydrogen Production from Xylose by Thermotoga neapolitana DSM 4359. International Journal of Hydrogen Energy, 35, 6657-6664. https://doi.org/10.1016/j.renene.2011.06.015

[18] Singh, L., Wahid, Z.A., Muhammad, F.S., Ahmad, A., Rahim, M.H.A. and Sakinah, M. (2013) Biohydrogen Production from Palm Oil Mill Effluent Using Immobilized Clostridium butyricum EB6 in Polyethylene Glycol. Process Biochemistry, 48, 294-298. https://doi.org/10.1016/j.procbio.2012.12.007

[19] An, D., Li, Q., Wang, X.Q., Yang, H. and Guo, L. (2014) Characterization on Hy- 
drogen Production Performance of a Newly Isolated Clostridium beijerinckii YA001 Using Xylose. International Journal of Hydrogen Energy, 39, 19928-19936. https://doi.org/10.1016/j.ijhydene.2014.10.014

[20] Chae, K.J., Choi, M.J., Kim, K.Y., Ajayi, F.F., Chang, I. and Kim, I.S. (2010) Selective Inhibition of Methanogens for the Improvement of Biohydrogen Production in Microbial Electrolysis Cells. International Journal of Hydrogen Energy, 35, 13379-13386. https://doi.org/10.1016/j.ijhydene.2009.11.114

[21] Mangayil, R., Santala, V. and Karp, M. (2011) Fermentative Hydrogen Production from Different Sugars by Citrobacter sp. CMC-1 in Batch Culture. International Journal of Hydrogen Energy, 36, 15187-15194. https://doi.org/10.1016/j.ijhydene.2011.08.076

[22] Markov, S.A., Averitt, J. and Waldron, B. (2011) Bioreactor for Glycerol Conversion into $\mathrm{H}_{2}$ by Bacterium Enterobacter aerogenes. International Journal of Hydrogen Energy, 36, 262-266. https://doi.org/10.1016/j.ijhydene.2010.09.090

[23] Khanna, N., Kotay, S.M., Gilbert, J.J. and Das, D. (2011) Improvement of Biohydrogen Production by Enterobacter cloacae IIT-BT 08 under Regulated pH. Journal of Biotechnology, 152, 9-15. https://doi.org/10.1016/j.jbiotec.2010.12.014

[24] Roy, S., Vishnuvardhan, M. and Das, D. (2014) Improvement of Hydrogen Production by Newly Isolated Thermoanaerobacterium thermosaccharolyticum IIT BT-ST1. International Journal of Hydrogen Energy, 39, 7541-7552. https://doi.org/10.1016/j.ijhydene.2013.06.128

[25] Pan, C.M., Fan, Y.T., Zhao, P. and Hou, H.W. (2008) Fermentative Hydrogen Production by the Newly Isolated Clostridium beijerincki Fanp3. International Journal of Hydrogen Energy, 33, 5383-5391. https://doi.org/10.1016/j.ijhydene.2008.05.037

[26] Long, C., Cui, J., Liu, Z., Liu, Y., Long, M. and Hu, Z. (2010) Statistical Optimization of Fermentative Hydrogen Production from Xylose by Newly Isolated Enterobacter sp. CN1. International Journal of Hydrogen Energy, 35, 6657-6664. https://doi.org/10.1016/j.ijhydene.2010.04.094

[27] Nguyen, T.H.H., Pham, D.N., Tran, M.H., Tien, N.A. and Ha B.T.V. (2016) Effects of Environmental Parameters on Hydrogen Production of Strain Clostridium beijerinckii CB3 Isolated in North of Vietnam under Anaerobic Condition. VNU J. Science. Natural Sciences and Technology, 32, 112-116.

[28] Taguchi, F., Chang, J.D., Mizukami, N., Saito-Taki, T., Hasegawa, K. and Morimoto M. (1993) Isolation of a Hydrogen-Producing Bacterium, Clostridium beijerinckii Strain AM21B, from Termites. Canadian Journal of Microbiology, 39, 726-730. https://doi.org/10.1139/m93-105

[29] Shiyan, S.P. and Krishnaveni, M. (2013) Hydrogen Production by Pseudomonas stutzeri JX442762 Isolated from Thermal Soil at Mettur Power Station, Salem District, Tamil Nadu, India. Journal of Pharmacy Research, 6, 112-116.

https://doi.org/10.1016/j.jopr.2012.11.024

[30] Amann, R.I., Ludwig, W. and Schleifer, K.H. (1995) Phylogenetic Identification and in Situ Detection of Individual Microbial Cells without Cultivation. Microbiology \& Molecular Biology Reviews, 59, 143-169. https://doi.org/10.1128/MMBR.59.1.143-169.1995

[31] Llewellyn, M.S., Boutin, S., Hoseinifar, S.H., Derome, N. (2014) Teleost Microbiomes: the State of the Art in Their Characterization, Manipulation, and Importance in Aquaculture and Fisheries. Frontiers in Microbiology, 5, 207. https://doi.org/10.3389/fmicb.2014.00207

[32] Llewellyn, M.S., McGinnity, P., Dionne, M., Letourneau, J., Thonier, F., Carvalho, 
G.R., Creer, S. and Derome, N. (2016) The Biogeography of the Atlantic Salmon (Salmo salar) Gut Microbiome. ISME Journal, 10, 1280-1284. https://doi.org/10.1038/ismej.2015.189

[33] Doetsch, R.N. (1981) Determinative Methods of Light Microscopy. In: Gerhardt, P., Murray, R.G.E., Costilow, R.N., Nester, E.W., Wood, W.A. and Krieg, N.R., Eds., Manual of Methods for General Bacteriology, American Society for Microbiology, Washington DC, 21-33.

[34] Dong, X.Z. and Cai, M.Y. (2001) Identification Manual of Systematic Bacteriology. Science Press, Beijing, 267-294.

[35] Van Soest, P.J., Robertson, J.B. and Lewis, B.A. (1991) Methods for Dietary Fiber, Neutral Detergent Fiber, and Non-Starch Polysaccharides in Relation to Animal Nutrition. Journal of Dairy Science, 74, 3583-3597. https://doi.org/10.3168/jds.S0022-0302(91)78551-2

[36] Chen, X., Sun, Y., Xiu, Z., Li, X. and Zhang, D. (2006) Stoichiometric Analysis of Biological Hydrogen Production by Fermentative Bacteria. International Journal of Hydrogen Energy, 31, 539-549. https://doi.org/10.1016/j.ijhydene.2005.03.013

[37] Wu, K.J., Lin, Y.H., Lo, Y.C., Chen, C.Y., Chen, W.M. and Chang, J.S. (2011) Converting Glycerol into Hydrogen, Ethanol, and Diols with a Klebsiella sp. HE1 Strain via Anaerobic Fermentation. Journal of the Taiwan Institute of Chemical Engineers, 42, 20-25. https://doi.org/10.1016/j.jtice.2010.04.005

[38] Chookaew, T., O-Thong, S., Prasertsan, P. (2012) Fermentative Production of Hydrogen and Soluble Metabolites from Crude Glycerol of Biodiesel Plant by the newly Isolated Thermotolerant Klebsiella pneumoniae TR17. International Journal of Hydrogen Energy, 37, 13314-13322. https://doi.org/10.1016/j.ijhydene.2012.06.022

[39] Chookaew, T., O-Thong, S. and Prasertsan, P. (2014) Biohydrogen Production from Crude Glycerol by Immobilized Klebsiella sp. TR17 in a UASB Reactor and Bacterial Quantification under Non-Sterile Conditions. International Journal of Hydrogen Energy, 39, 9580-9587. https://doi.org/10.1016/j.ijhydene.2014.04.083

[40] Fang, H.H.P. and Liu, H. (2002) Effect of $\mathrm{pH}$ on Hydrogen Production from Glucose by Mixed Culture. Bioresource Technology, 82, 87-93. https://doi.org/10.1016/S0960-8524(01)00110-9

[41] Nath, K., Kumar, A. and Das, D. (2006) Effect of Some Environmental Parameters on Fermentative Hydrogen Production by Enterobacter cloacae DM11. Canadian Journal of Microbiology, 52, 525-532. https://doi.org/10.1139/w06-005

[42] Ren, N., Cao, G., Wang, A., Lee, D.J., Guo, W. and Zhu, Y. (2008) Dark Fermentation of Xylose and Glucose Mix Using Isolated Thermoanaerobacterium thermosaccharolyticum W16. International Journal of Hydrogen Energy, 33, 6124-6132. https://doi.org/10.1016/j.ijhydene.2008.07.107

[43] Biebl, H., Zeng, A.P., Menzel, K. and Deckwer, W.D. (1998) Fermentation of Glycerol to 1,3-Propanediol and 2,3-Butanediol by Klebsiella pneumonia. Applied Microbiology \& Biotechnology 50, 24-29. https://doi.org/10.1007/s002530051251 